\title{
Evaluation of Cadmium Contaminated Roadside Soil Surface and its Transfer to Animals through Forage: Assessing the Health Risk Assessment for Ruminants
}

\author{
KAFEEL AHMAD ${ }^{1}$, NIMRA ARSHAD ${ }^{1}$, ZAFAR IQBAL KHAN ${ }^{*}$, HUMAYUN BASHIR ${ }^{1,2}$, \\ SONAINA NAZAR ${ }^{1}$, KINZA WAJID ${ }^{1}$, MUDASRA MUNIR ${ }^{1}$, KHADIM HUSSAIN ${ }^{3}$, \\ MUHAMMAD NADEEM ${ }^{4}$, SALEH ALFARRAJ ${ }^{5}$, IFRA SALEEM MALIK ${ }^{1}$, \\ SULAIMAN ALI ALHARBI ${ }^{6}$ \\ ${ }^{1}$ Department of Botany, University of Sargodha, University Road, 40100, Sargodha, Pakistan \\ ${ }^{2}$ Institute of Molecular Biology and Biotechnology, University of Lahore, Defense Road, 54792, Lahore, Pakistan \\ ${ }^{3}$ Department of Botany, Govt. Muhamadan Anglo Oriental (MAO) College, Lower Mall, 54000, Lahore, Pakistan \\ ${ }^{4}$ Institute of Food Science and Nutrition, University of Sargodha, University Road, 40100, Sargodha, Pakistan \\ ${ }^{5}$ Zoology Department, College of Science, King Saud University, Riyadh 11451, Saudi Arabia \\ ${ }^{6}$ Department of Botany and Microbiology, College of Science, King Saud University, P. O. Box 2455 Riyadh 11451, \\ Saudi Arabia
}

\begin{abstract}
The increasing pollution in most industrialized area is a really attention seeking issue now a days. Air pollution caused by vehicular smoke contains handsome percentages of heavy metals like cadmium. Cadmium like other heavy metals accumulated in the bodies of living systems found around roads. Among the living system cadmium accumulate up to alarming rate like in soil, plants and animals. Therefore, this study was conducted in order to evaluate the possible risk of the Cadmium on the soil, forage and buffalos. The study was done in the area of Sargodha district, Punjab, Pakistan. There were six sites selected for study on accumulation of Cd in the forages, soil and the Buffalo blood. The Cd content in soil samples was highest in sample collected from site III. The Cd content was highest in the forage sample collected from site IV and in the blood samples, and the bioaccumulation factor was highest in the samples collected from site $V$. The positive and non-significant correlation was found when soil and forage was correlated, unlike the correlation found between blood and forage which was found negative non-significant. The samples from site III showed high daily intake of metals, health risk index, and pollution load index. This study will bring attention towards the development of the strategies in order to be safe from the toxic effects of cadmium.
\end{abstract}

Keywords: sources, automobiles, bioaccumulation, Daily intake of metals

\section{Introduction}

The concerning topic now-a-days is the heavy metal toxicity in the living environment. The heavy metals are equally toxic to animals, plants and humans. The toxicity of heavy metals is elevated due to their accumulation in the living systems of the living bodies. In cities there are various sources of heavy metals by which these move to the sinks. Among the sources of heavy metals in top layer of soil, the automobile smoke is very important [1]. The pipes, wires and tires are the major source of heavy metals like $\mathrm{Zn}, \mathrm{Cu}$ and $\mathrm{Fe}$, which are added to environment by mechanical abrasion [2]. The sources of heavy metals like automobile smoke in air get precipitated on soil [3]. The heavy metals are referred to the elements which persist in the aquatic and terrestrial environment and are non-biodegradable species. The heavy metals can be transported into the plants by various pathways, so the interaction of the heavy metals is quite important to be studied in order to be safe from the toxic effects of the heavy metals. This study aims at determining heavy metal concentrations in the automobile contaminated soil, forage and buffalo blood plasma.

*email: zafar.khan@uos.edu.pk 


\section{Materials and methods}

\subsection{Study site}

The study was conducted in Sargodha, Pakistan, which lies in $73^{\circ} 7^{\prime} 00^{\prime \prime}$ east longitude and $32^{\circ} 08^{\prime} 00^{\prime \prime}$ north latitude. The climate of Sargodha is about $5-23^{\circ} \mathrm{C}$ in winter while $35-49^{\circ} \mathrm{C}$ in summer. Sargodha is connected by highway to other cites of Punjab and is -about 30 miles away from highway. The sampling for winter season was done in December 2016 and January 2016 while the summer sampling was done in May and June 2016.

\subsection{Forage and soil samples}

Four types of forages (Gandum, Sorghum, Millet and Berseem) along with their soil was collected from six sampling sites of Sargodha in summer and winter seasons. There were about 120 samples of each forage and soil, from each site. Among the six sites of Sargodha, five sites were roadsides e.g. Mateela, Faisalabad road side, Shaheenabad road, Bhalwal road, 50 Chak, while Dera Saudi was away from road. The air drying and oven drying of the samples was followed by crushing and grinding. $1 \mathrm{~g}$ sample of soil and $0.5 \mathrm{~g}$ sample of each forage was saved for acid digestion.

\subsection{Blood samples}

The blood sampling was done as 60 samples of buffalo blood from six sites. The blood samples were collected in sterilized test tubes $(16 \times 150 \mathrm{~mm})$. The test tubes were left for the proteins to get coagulated and serum separated. All blood samples were centrifuged (at $3000 \mathrm{rpm}$ for 15-30 min) to separate blood plasma from blood serum. Blood serum samples were saved at $20^{\circ} \mathrm{C}$ until further analysis.

\subsection{Digestion of samples}

The sample of forages and soil (1g) were digested using two acids $\mathrm{HClO}_{4}$ and $\mathrm{HNO}_{3}$ in ratio 1:3. This solution was heated on hot plate at $250^{\circ} \mathrm{C}$ for about $3-4 \mathrm{~h}$. The heating of solution was continued until the colorless solution was obtained [4]. The acid digestion of the $0.5 \mathrm{~g}$ of soil sample was done by using oxidizing agents like sulphuric acid and hydrogen peroxide. The sample was diluted up to $50 \mathrm{~mL}$ and saved [5]. The samples of the buffalo blood were digested by adding $2.5 \mathrm{~mL}$ of nitric acid and $5 \mathrm{~mL}$ sulphuric acid. Heating was continued until the solution become colorless. The remaining sample was saved for further procedure after the dilution [6]. The procedure of the digestion of the soil, forage and blood sample was followed by cadmium analysis in the samples by using atomic absorption spectrophotometry by Flame Atomic Absorption Spectrophotometer AA 6300 Shimadzu Japan.

\subsection{Statistical analysis}

The data obtained by the atomic absorption spectrophotometer was then analyzed statistically in order to form summarized results of this study. ANOVA and SPSS software version no. 20 was used to find the mean concentrations of the cadmium in samples and correlation. The socio-demographic characteristics of the respondents as well as the perceptions of the respondents to roadside-sun drying practice were analyzed using frequency distribution [7].

\subsection{Bioaccumulation factor (BAF)}

The ratio of total concentration of the cadmium in forage as compared to soil and the soil is called as bioaccumulation factor.

Bioaccumulation factor $=\mathrm{C}_{\text {forage }} / \mathrm{C}_{\text {soil }}[8]$.

\subsection{Health risk index}

The health risk index was calculated according to formula given by [8].

$(\mathrm{HRI})=\mathrm{DIM} / \mathrm{RfD}[9]$.

The Reference value for Cd is $0.001 \mathrm{mg} / \mathrm{kg} /$ day [10]. 


\subsection{Daily intake of Metal}

Daily intake of metal $(\mathrm{DIM})=\mathrm{C}_{\text {metal }} \times \mathrm{D}_{\text {food intake }} / \mathrm{B}_{\text {average weight }}[10]$.

The daily consumption of forage was $12.5 \mathrm{~kg}$ while body weight of cattle was taken as $550 \mathrm{~kg}$ [11].

\subsection{Pollution load index}

The formula of pollution load index was calculated by [12].

$\mathrm{PLI}=\mathrm{Cd}$ in investigated soil site $\left(\mathrm{C}_{\text {soil }} /\right.$ reference value of the $\mathrm{Cd}$ in soil $\left(\mathrm{C}_{\text {reference value }}\right)$

The reference valued of $\mathrm{Cd}$ in soil was $1.49 \mu \mathrm{g} / \mathrm{g}$, dry matter [13].

\section{Results and discussions}

\subsection{Mineral Analysis}

\subsubsection{Soil}

The analysis of soil data showed non-significant effect $(\mathrm{P}>0.05)$ of sites, seasons and sites $\times$ seasons on Cd content (Table 1). Cd content in soil samples at six sites of sampling was as: site III > site II $>$ site VI>site I $>$ site IV > site V (Table 2, Figure 1). The mean value of $\mathrm{Cd}$ as found in soil samples of present study was higher than the concentration of Cd- 0.28 as reported by [14]. While no considerable difference in $\mathrm{Cd}$ content was found between the Cd content in the forage samples of Sargodha and in the study done by [15]. The elevated automobiles on the roads release a handsome percentage of extremely toxic smoke enriched with many heavy metal like cadmium which may be one of the reason of the presence of cadmium in soil samples collected from various sites of Sargodha. On the other hand the soil of the humid regions contains less cadmium concentration unlike the soil of the arid and semi-arid regions. However in the areas where there is less industrial set up along with limited anthropogenic activities, there is less Cd content in soil samples [16].

Table 1. ANOVA for Cd concentration in soil $(\mathrm{mg} / \mathrm{kg})$

\begin{tabular}{|c|c|c|}
\hline Source of Variations & Degree of freedom & Mean square \\
\hline Sites & 5 & $12.89^{\text {ns }}$ \\
\hline Seasons & 1 & $28.79^{\text {ns }}$ \\
\hline Sites $\times$ seaosns & 5 & $13.85^{\text {ns }}$ \\
\hline Error & 36 & 14.78 \\
\hline
\end{tabular}

Table 2. Analysis of variance for heavy metals in forage at six sites of sampling $(\mathrm{mg} / \mathrm{kg})$

\begin{tabular}{|c|c|c|}
\hline Source of Variations & Degree of freedom & Mean square \\
\hline Sites & 5 & $0.698^{\mathrm{ns}}$ \\
\hline Seasons & 1 & $0.421^{\mathrm{ms}}$ \\
\hline Sites $\times$ seaosns & 5 & $0.813^{\mathrm{ns}}$ \\
\hline Error & 36 & $0.114^{\mathrm{ns}}$ \\
\hline
\end{tabular}

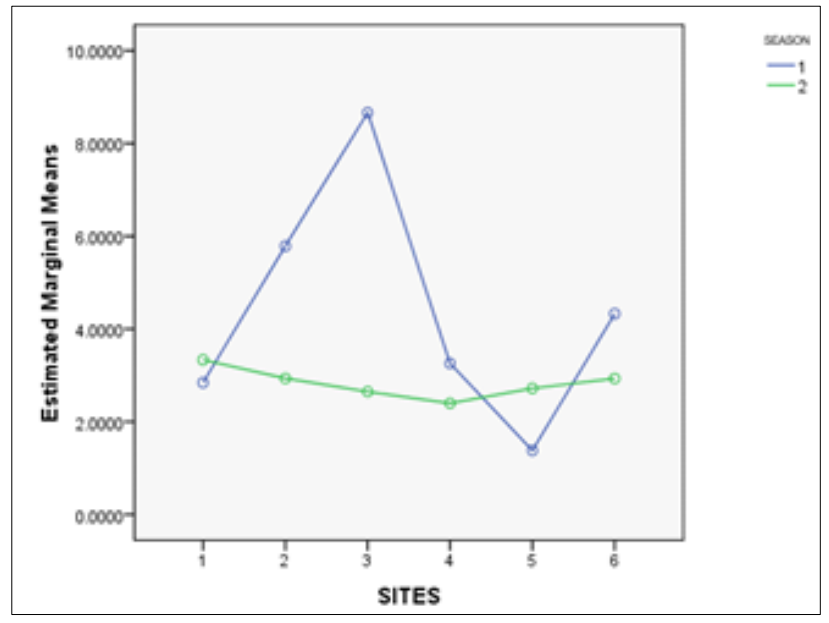

Figure 1. The fluctuations of $\mathrm{Cd}$ in soil $(\mathrm{mg} / \mathrm{kg})$ at six sites of sampling 


\subsubsection{Forage}

The analysis of forage data showed non-significant effect $(\mathrm{P}>0.05)$ of sites, seasons and sites $\times$ seasons on Cd content (Table 3). Cd content in forage samples at six sites of sampling was as: site VI $>$ site III $>$ site IV $>$ site I $>$ site $\mathrm{V}>$ site II $>$ site I respectively (Table 3, Figure 2).

The heavy metal levels studied by John and his team [17], showed higher Cd content in forage samples compared to that found in this study. According to Word and his collaborators [18], it was reported that the accumulation of $\mathrm{Cd}$ along with other heavy metals in soils is caused by the emission of dangerous and poisonous gases from the vehicles. On the other hand it was also reported that the distance of forages from busy roads of heavy traffic influences the accumulation of the $\mathrm{Cd}$ in these forages [19]. The mean concentrations of $\mathrm{Cd}$ were similar in present study as compared to those studied [20, 21] reported that the botanical composition of the soil i.e., the structure of soil, fertility of soil, the $p \mathrm{H}$ of the soil affect the heavy metal transfer to the forages. Lower automobile exhaust in the sampling site of Sargodha is responsible for the lower heavy metal contents in forages.

Table 3. Cd contents in soil, forages $(\mathrm{mg} / \mathrm{kg})$ and buffalo blood $(\mathrm{mg} / \mathrm{L})$

\begin{tabular}{|c|c|c|c|}
\hline Sites & Soil & Forages & Blood \\
\hline Site I & 3.809 & 0.983 & 2.112 \\
\hline Site II & 14.361 & 1.476 & 3.190 \\
\hline Site III & 5.655 & 1.775 & 2.319 \\
\hline Site IV & 2.828 & 1.567 & 3.152 \\
\hline Site V & 2.051 & 1.520 & 3.341 \\
\hline Site VI & 3.630 & 1.800 & 3.053 \\
\hline
\end{tabular}

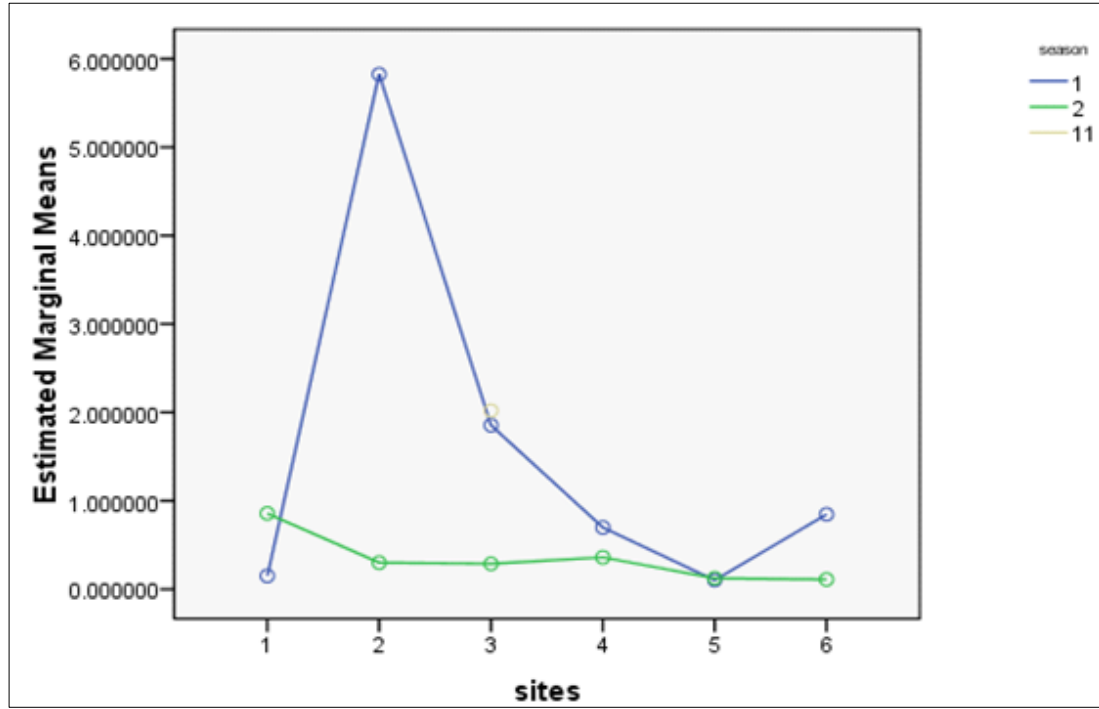

Figure 2. The fluctuation in $\mathrm{Cd}$ in forage $(\mathrm{mg} / \mathrm{kg})$ at six sites of sampling

\subsubsection{Blood}

Analysis of Buffalo blood data showed non-significant effect $(\mathrm{P}>0.05)$ of sites, seasons and sites $\times$ seasons on $\mathrm{Cd}$ content (Table 4 ). Cd content in blood samples at six sites of sampling was as: site V $>$ site II $>$ site IV $>$ site VI $>$ site $>$ site III $>$ site I respectively (Table 4, Figure 3 ).

The trend of $\mathrm{Cd}$ content that come out as a result of this study was in the same concentration as found in the study done by Olukam and his team [22], $(\mathrm{Cd}-0.021 \mathrm{mg} / \mathrm{kg})$. The trend of heavy metals in blood studied by Aslam and his collaborators [23] , was a bit different from that found in this study. Cd content was lower in the study as found by Aslam et al. [23]. Cd content retained in the sensitive organs of body like liver and kidneys which further lead to poisoning [24]. The management of metallurgical waste and road side smoke should be properly managed in order to keep the cattle safe from the dangerous effects of toxic heavy metals. 
Table 4. ANOVA for heavy metals in Buffalo Blood at six sites of sampling $(\mathrm{mg} / \mathrm{L})$

\begin{tabular}{|c|c|c|}
\hline Source of Variations & Degree of freedom & Mean square \\
\hline Sites & 5 & $2.10^{\text {ns }}$ \\
\hline Seasons & 1 & $9.74^{\text {ns }}$ \\
\hline Sites $\times$ seaosns & 5 & $2.452^{\text {ns }}$ \\
\hline Error & 36 & 2.556 \\
\hline ns=Non-significant $*=$ Significant at $0.05, * *=$ Significant at $0.01, * * *=$ Significant at 0.001
\end{tabular}

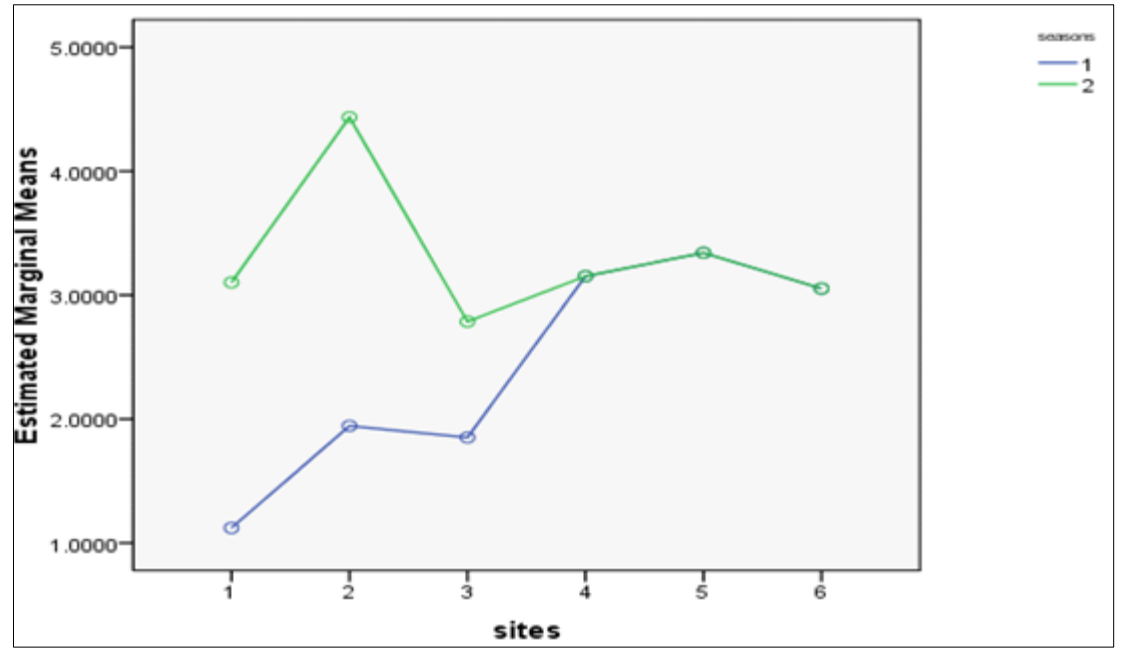

Figure 3. The fluctuation of $\mathrm{Cd}$ in blood $(\mathrm{mg} / \mathrm{L})$ at six sites of sampling

\subsection{Bioaccumulation factor for forage}

For forage the order of bioaccumulation factor at the six sites of sampling was: Site V>Site IV>site VI $>$ site II $>$ site I $>$ site III respectively (Table 5).

The higher bioaccumulation factor for $\mathrm{Cd}$ at site $\mathrm{V}$ indicates that $\mathrm{Cd}$ was more bioavailable at this site of sampling. The bioaccumulation factor also depends upon soil $p \mathrm{H}[25,26]$. The soil properties like its $p \mathrm{H}$ influence the mobility of heavy metals in soil. The movement of the heavy metals was restricted by high value of $p \mathrm{H}$ unlike in case of low $p \mathrm{H}$ heavy metals mobility from soil to plants [27]. It may be possible that the $p \mathrm{H}$ of examined soil affect the bioconcentration factor of heavy metals.

\subsubsection{Bioaccumulation factor for blood and forage}

For forage the order of bioaccumulation factor at the six sites of sampling was: Site V>Site II $>$ site I $>$ site IV>site VI $>$ site III respectively (Table 5). Opulwa et al. [28] reported higher cadmium concentration $\mathrm{s}$ in the samples of forages unlike the samples of forages analyzed in the current study [29], also reported higher cadmium concentrations in the forage samples. Lower retention of the heavy metals in soil lead to higher bioaccumulation factor while the tight bonding of the heavy metals with soil does not allow heavy metals to get transferred to forage and thus the bioaccumulation factor is lower.

Table 5. Bio concentration factor of $\mathrm{Cd}$ in forages and buffalo blood

\begin{tabular}{|c|c|c|}
\hline Sites & Forages & Buffalo blood \\
\hline Site I & 0.318 & 2.14 \\
\hline Site II & 0.338 & 2.16 \\
\hline Site III & 0.313 & 1.306 \\
\hline Site IV & 0.554 & 2.011 \\
\hline Site V & 0.74 & 2.198 \\
\hline Site VI & 0.49 & 1.696 \\
\hline
\end{tabular}




\subsection{Correlation}

The results showed positive and non-significant correlation for $\mathrm{Cd}$ when soil and forage were correlated. When blood-forage was correlated the result showed negative non-significant correlation for Cd (Table 6).

In the current study the soil-forage and blood-forage cadmium heavy metal concentrations were correlated separately. The trend of correlation found by Amlan and his team [30], was different compared to this study, and it was highest for $\mathrm{Cd}$. More complicated relationship between soil and forage leads to negative non-significant correlation while a strong relationship is responsible for the positive non-significant correlation. Positive non-significant correlation for $\mathrm{Cd}$ was observed, which suggested an equalization stream of this metal among soil and forages. More convoluted relationship of heavy metals suggesting imbalance of cadmium between soils, was one of the reason behind negative nonsignificant correlation Effective translocation of heavy metals from soil was one of the reasons behind the positive correlation found for $\mathrm{Cd}$ [31]. The high correlation of cadmium caused higher bioavailability of cadmium.

Table 6. Metal and metalloid correlation between soil-vegetable at three sites

\begin{tabular}{|c|c|c|}
\hline Correlation & Soil-forage & Blood-forage \\
\hline $\mathrm{Cd}$ & 0.49 & -0.449 \\
\hline
\end{tabular}

\subsection{Daily Intake of Metal}

The order of bio-concentration factor at the six sites of sampling was Site III $>$ Site VI $>$ site IV $>$ site V>site II > site I respectively (Table 7).

The trend of $\mathrm{Cd}$ was different from that found in present study, because $\mathrm{Cd}$ was found lower in this study unlike the study of Radwan and his team [32] as Cd-124. In the current results the values of daily intake of metals were lower than one and it suggests that no risk of health is associated with the consumption of such contaminated forages [33].

\subsection{Health Risk Index}

The order of Health Risk Index (HRI) at the six sites of sampling was Site III $>$ Site IV > site V > site II $>$ site I $>$ site VI respectively (Table 7).

USEPA [9] reported that if after the statistical analysis of the data value of HRI comes out to be less than one it means no considerable health risk is associated with the consumption of the contaminated forages unlike the Value of HRI more than one. According to Ahmad and his team [34], if the HRI is found greater than one, it means a serious health risk is associated with the consumption of roadside contaminated forages. Health risk index depend on the chemical composition and the physical characteristics of soil, type of forage being consumed and rate of the consumption of forages.

\subsection{The Pollution load index (PLI)}

The order of Health risk Index at the six sites of sampling was Site III $>$ Site II $>$ site VI $>$ site I $>$ site IV>site $\mathrm{V}$ respectively (Table 7).

Table 7. Daily intake, HRI and PLI of metal via consumption of forage from six different sites of Sargodha District

\begin{tabular}{|c|c|c|c|}
\hline Sites & Daily intake & HRI & PLI \\
\hline Site I & 0.022 & 2.02 & 2.07 \\
\hline Site II & 0.033 & 3.03 & 2.92 \\
\hline Site III & 0.040 & 4.04 & 3.97 \\
\hline Site IV & 0.035 & 3.05 & 1.89 \\
\hline Site V & 0.034 & 3.045 & 1.37 \\
\hline Site VI & 0.036 & 1.09 & 2.43 \\
\hline
\end{tabular}


The report provided by Khan et al. [35], showed lower pollution load index caused by consumption of contaminated forages in contrast to the high values depicted in the current study. The criteria of determining degree of contamination by calculating PLI is given as: PLI lower than one means the area of the sampling is less polluted while on the other hand PLI value greater than one means area is much polluted.

\section{Conclusions}

The forages, soil and buffalos blood samples were collected from various sites of Sargodha, Pakistan. Drying and crushing of soil and forage samples were digested by using acids which were $\mathrm{HNO}_{3}, \mathrm{HClO}_{4}$ and $\mathrm{H}_{2} \mathrm{O}_{2}$. Blood serum was separated and these were also digested. Cadmium analysis of samples was done by atomic absorption Spectrophotometer. The statistical analysis of the data revealed that the forages, soil and buffalo blood contain higher cadmium concentration due to increased Cd released into atmosphere by heavy traffic. The decrease is due to the rush of traffic in the sampling area, which lowered the cadmium concentration in the samples.

Acknowledgment. The authors extend their appreciation to the Researchers Supporting Project Number (RSP-2020/7) King Saud University, Riyadh, Saudi Arabia.

\section{References}

1.KELLY, J., I. THORNTON, P.R. SIMPSON., Urban geochemistry: a study of influence of anthropogenic activity on heavy metal content of soils in traditionally industrial and non-industrial areas of Britain. Appl. Geochem., 11, 1996, 363-370

2.JARADAT, Q., A. MASADEH, M.A. ZAITOUN, B.M. MAITAH., Heavy metal contamination of soil, plant and air of scrapyard of discarded vehicles at Zarqa City, Jordan, Soil and Sediment. Contamin. Toxicol., 14, 2005, 449-462

3.HARRISON, R.M., D.P. LAXEN, S.J. WILSON., Chemical association of lead, cadmium, copper and zinc in street dust and roadside soil. Environ. Sci. Technol., 15, 1981, 1378-1383.

4.KOH, T.S., P.J. BABIDGE. A comparison of blood lead levels in dogs from a lead-mining, leadsmelting, urban and rural island environment. Aust. Vet. J.,63, 1986, 282-285.

5.COOK, K.K., Extension of Dry Ash Atomic Absorption and Spectrophotometric Methods to Determination of Minerals in Soy-Based, Whey-Based and Enteral Formulae (Modification of AOAC Official Methods 985.35 and 986.24): Collaborative Study; J. AOAC Int., 80, 1997, 834-44.

6.GAFAR, H.M. Accumulation of some heavy metals in hair, plasma and milk of cattle and buffalos grazing berseem or red plants in Egypt. Egyp. J. Anim. Prod., 45(2), 2008, 71-78.

7.STEEL, R., J.H. TORRIE, Principle and procedures of statistics, a biometrical approach ( $2^{\text {nd }}$ ED). McGraw Hill Book Co. Inc., New York, 1980, 336-354.

8.SAINGER, P., A. DHANKHAR, R. SAINGER, M. KAUSHIK, R.P. SINGH., Assessment of heavy metal tolerance in native plant species from soils contaminated with electroplating effluent, Ecotoxicol. Environ. Saf., 74, 2011, 2284-2291.

9.*** USEPA (US Environmental Protection Agency), 2002. Region 9, Preliminary Remediation Goals. 10.***USEPA. 2010. Renewable fuel standard program (RFS2) regulatory impact analysis. US Environmental Protection Age.

11.BRIGGS, H., H.M. BRIGGS., Modern breeds of livestock. Fourth edition Mc Million publishing Co. 1990

12.LIU, W.H. ZHAO J.Z., OUYANG, Z.Y. SODERLUND, L. LIU, Impacts of sewage irrigation on heavy metal distribution and contamination in Beijing, China. Environ Int. 31, 2005, 805-812.

13.SINGH, A. SHARMA, R.K. AGARWAL, F.M. MASHAL. Health risk assessment of heavy metals via dietary intake of foodstuffs, from waste water irrigated site of dry tropical area of India. Fd. Chem. Toxicol., 48, 2010, 611-619 
14.NAZIR, R.., M. KHAN, M. MASAB, H. REHMAN, N. RAUFI, S. SAHABI, N. AMEERI, M.SAJEDI, M. ULLAH, Z. SHAHEEN, Accumulation of Heavy Metals (Ni, Cu, Cd, Cr, Pb, Zn, Fe) in the soil, water and plants and analysis of physico-chemical parameters of soil and water Collected from Tanda Dam kohat). J. Pharm. Sci. Res. 7(3), 2015, 89-97

15.MARIANNA, BANDIERA, C. CORTIVO, G. BARION, G. MOSCA, TEOFILO VAMERALI, Phytoremediation Opportunities with Alimurgic Species in Metal-Contaminated Environments. Pak. J. Bot., pp: 213, 2016.

16.AKSOY, A., M.A. OZTURK. Nerium oleander L. as a Biomonitor of Lead and Other Heavy Metal Pollution in Mediterranean Environments. Sci. Tot. Environ. 205, 1997, 145-150.

17.JOHN, R., P. AHMAD, K. GADGIL, S. SHARMA, Heavy metal toxicity: Effect on plant growth, biochemical parameters and metal accumulation by Brassica juncea L. Int. J. Plant Produc., 3(3), 2013, 65-76.

18.***WORD, N., L.R. BROOKS, R.R. ROBERTS, Heavy metal pollution from automotive emissions and its effect on roadside soils and pasture species in New Zealand". Environ. Sci. Technol., 11, 1977, 917-920.

19.NASER, M., A. VAZIRZADEH, R. KAZEMI, F. ZAHERI, Concentration of some heavy metals in rice types available in Shiraz market and human health risk assessment. Food chem., 175, 2012, 243248.

20.OGUNDIRAN. M.B. OGUNDELE, D.T, AFOLAYAN P. G., O. OSIBANJO, Lead, Cd, Cu and Zn levels in forage grasses, leachate and lactating cows reared around lead slag dumpsites in Nigeria Int. $J$. Environ. Res., 6(3), 2012, 695-702

21.HUSTON, J.E., WHITE, R.G., BEQUETTE, B.J., DOVE, H., GOETSCH, A.L., HESS, B.W., BRAVO, M.H, PUGH, D.G., SOLAIMAN, Nutrient Requirements of Small Ruminants: Sheep, Goats, Cervids, and New World Camelids. The National Academies Press. 2006. Washington, D.C.

22.OLUKAM, J.A., A. K. FAJIMI, A.O. ADEBAYOB, F. T. AJAYI, Lead and Cadmium poisoning of goat raised in cement klin dust polluted area. J. Food Agric. Environ.,5, 2007, 382-384.

23.ASLAM, S., F. SHARIF, A.U. KHAN, Effect of lead and cadmium on growth of Medicago sativa L. and their transfer to food chain. J. Anim. Plant Sci., pp: 25(2), 2005.

24.MINERVINO, A.H. JUNIOR, R. A.B. FERREIRA, R.N. F., RODRIGUES, F. A. M. L., HEADLEY, S. A., MORI, C. S., E.L. ORTOLANI, Clinical observations of cattle and buffalos with experimentally induced chronic copper poisoning. Res. Vet. Sci., 87, 2009, 473-478.

25.ZHANG, H. LOU, Y. SONG, J. ZHANG, H. XIA, J. ZHAO, Predicting As, Cd and Pb uptake by rice and vegetables using fields data from China. J. Environ. Sci., 23, 2007, 70-78.

26.CUI, Y.L., R.H. ZHU, R.H. ZHI, D.Y. CHEN, Y.Z. HUANG, Y.QIU, Transfer of metals from soils to vegetables in an area near a smelter in Nanning, China. Environ. Int.,30, 2004, 785-791.

27.CELECHOVSKA, O., L. MALOTA, Z. ZIMA., Entry of heavy metals into food chains: a 20-years comparison study in the Northern Moravia (Czech Republic). Act. Vet. Brnao, 77, 2008, 645-652

28.OPUlWA, O. D, M. O. AREMU, L. O. GOGBO, K. A. ABIOLA, I. E. ODIBA, M. M. ANUBAKAR, N.O. NWEZE., Heavy metal concentrations in soils, plants leaves and crops grown around dump sites in Lafia Metropolis, Nasarawa State, Nigeria, Advances in Applied Science Research 3 (2), 2012,780-784

29.KAMAL, K.T., K. LOFTI, K.D. OMER, R.E. MOHAMMAD, K.B. OBULEIZ, Heavy metals concentrations in fish from Red sea and Arabian gulf. Health benefits and risk assessments due to their consumptions. Asi. J. Chem., 27, 2015, 4411-4416.

30.AMLAN, K., M.A. GHOSH, H.P. BHATT, AGRAWAL, Effect of long-term application of treated sewage water on heavy metal accumulation in vegetables grown in Northern India. Environ Monit Assess., 184, 2012, 1025-1036 
31.SASKIA, A., N. YAMAJI, K. YOKOSHO, J. F. MA, Nramp5 is a major transporter responsible for manganese and cadmium uptake in rice. The Plant Cell, 24(5), 2013, 2155-2167

32.RADWAN, M.A., A.K. SALAMA, Market basket survey for some heavy metals in Egyptian fruits and vegetables. Food Chem. Toxicol., 44, 2006, 1273-1278.

33.SAJJAD, K., R. FAROOQ, S. SHAHBAZ, M.A. KHAN AND M. SADIQUE, Health risk assessment of heavy metals for population via consumption of vegetables. World Appl. Sci. J., 6, 2009, 1602-1606. 34.AHMAD, K., Z.I. KHAN, A. ASHFAQ, M. ASHRAF, S. YASMIN, Assessment of heavy metal and metalloid levels in spinach (Spinacia oleracea L.) grown in wastewater irrigated agricultural soil of Sargodha, Pakistan. Pak. J. Bot., 46(5), 2014, 1805-181

35.KHAN, Z.I., AHMED, K. ASHRAF, K., PARVEEN, M., BIBI, R., MUSTAFA, Z., NOORKA, I.R., TAHIR, R., AKRAM, N.A., YAQOOB, M.F., TUFARELLI, R., FRACHHIOLA, V., CAZZATO, M., Risk assessment of heavy metal and metalloid toxicity through a contaminated vegetable (Cucurbita maxima) from wastewater irrigated area: A case study for a site-specific risk assessment in Jhang, Pakistan. Ecol. Risk. Assess., 22, 2014, 86-98

Manuscript received: 10.05 .2020 